\title{
OUTLINES OF THE MAFIC DYKE SWARM FROM LADIK AREA, NW KONYA/TURKEY
}

DOI: http://dx.doi.org/10.18509/GBP.2020.10

UDC: $\mathbf{5 5 2 . 5 4 . 0 8 ( 5 6 0 )}$

\author{
Kerim Kocak \\ Konya Technical University, Department of Geological Eng., Konya, Turkey
}

\begin{abstract}
The dyke swarm occurs in Ladik area, Central Turkey, exhibiting spectacular crosscutting field relationships between its different generations. The metadolerit and metahornblend gabro dyke swarms intruded into Silurian-lower Carboniferous reefal complex metacarbonates, which was low-grade metamorphosed limestone, dolomitic limestone and dolomite, with metachert band and lenses. A Google Earth Image is used to establish the relative emplacement of dyke swarms while image analyses used by Klonk software to reveal the length and thickness of the dykes.

It has been determined existence of two set of mafic dyke swarms; trending in (i) $\sim \mathrm{E}-\mathrm{W}$ and (ii) $\sim \mathrm{N}-\mathrm{S}$ directions. Maximum length and thickness of the dykes are calculated to be $3078 \mathrm{~m}$ (i), and $73.11 \mathrm{~m}$, respectively while the maximum length of fault can be traced as $743 \mathrm{~m}$ in the area. Cross-cutting field relations on the map suggest that majority of the E-W trending dyke swarms appears to be older than the N-S trending ones.
\end{abstract}

Keywords: Dike swarm, mafic, Ladik, Konya

\section{INTRODUCTION}

The study area is situated in Central Turkey, NW Konya, and the Afyon-Bolkardagi Zone [1] Kütahya-Bolkardağ belt [2] or Afyon zone [3], which is a thrust slice extending from western Anatolia to central Anatolia, with more than $600 \mathrm{~km}$ length (Figure 1a) .

Mafic dyke swarms are vertical dyke swarms in the similar orientation, representing the system of pre-formed stretched crustal fracture swarms in which the mafic magma is located [4] [5]. The dyke swarms also represent spreading structures and are commonly found on earth cratons (eg Canadian Shield, North China craton). In the study area, mafic dyke swarms were intruded into metacarbonates, and exhibit spectacular cross-cutting field relationships in the field. Google Earth Images and an image processing software (KLONK) are used to determine the length and thickness of the dykes and faults, and to establish the relative emplacement of dyke swarms.

\section{GEOLOGICAL SETTING}

Palaeozoic-Mesozoic metasedimentary and metaigneous rocks are exposed in northwest of Konya. The oldest formation exposed is the Silurian-Lower Permian (Sizma Group) rocks; the lower part of which is the middle Devonian and Early Carboniferous Bozdag Formation (Figure 1b, Figure 2), which represents a reefal complex including low-grade metamorphosed limestone, dolomitic limestone and dolomite, with metachert and beds and chert lenses. It has also barite lenses and bands, with thickness of 10-40 cm. The Bozdağ Formation shows transition vertically and laterally 


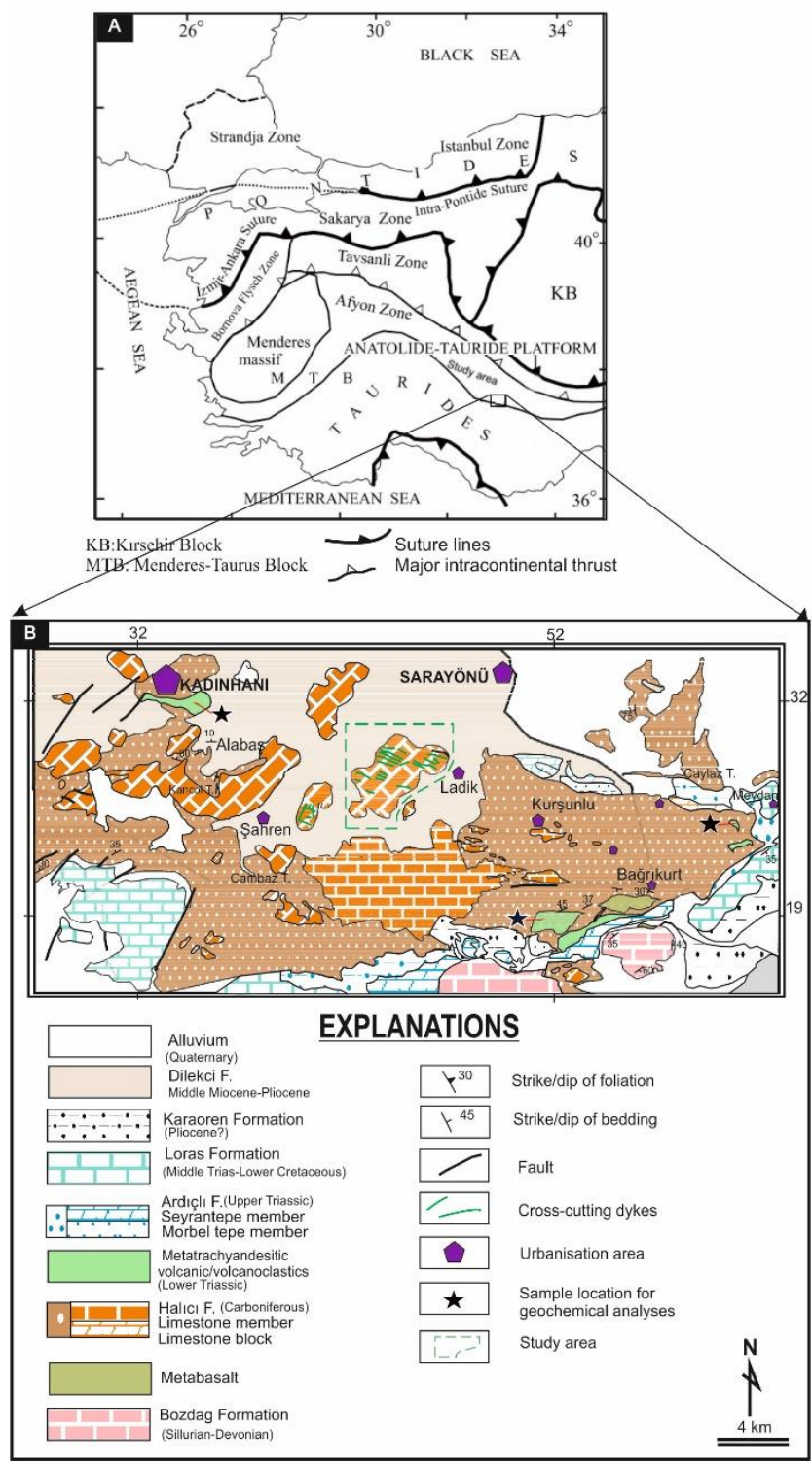

Figure 1. a) The location [6] and b) the geologic map of the study area, [7] [8].

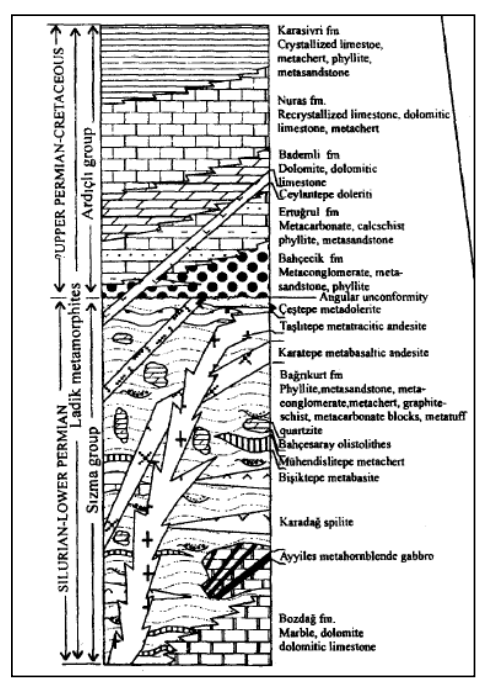

Figure 2. Generalized stratigraphic column of the area [9] 
to Devonian-Lower Permian Bağrikurt formation, which typically shows alternations of contains phyllite, graphite schist, metasandstone, metaconglomerate, and metachert layer, with some metacarbonate blocks as appearance of a wild-flysch. All these units were intruded by Kadinhani metamagmatic rocks including metagabbro, metadiabase, spilite and basaltic andesite [10] [11]. The transgressive Sizma Group unconformably overlain by the ?Upper Permian-Mesozoic continental metaclastics Ardiçli Group, and undergone at least four phases of deformation by the Alpine orogeny [11]

The dyke has light-dark green colour, and mostly metadiabase in composition. In the field, it is generally covered by its alteration products with dark colour and plants, which makes difficult to get fresh samples, but let us recognize, particularly on a Google Map (Figure 3). Fresh samples is usually found in quarries and road-cuttings, in where it shows more or less developed foliation. The subvertical mafic dyke swarm was intruded into the metacarbonates of Bozdag formation, and has grain size decreasing towards its contact with host metacarbonates.

A "Google Earth" image with large scale of the study area was captured to trace the mafic dyke swarms and cutting faults by Corel Photo Paint. The linear structures in the field were measured accurately after being drawn with the help of the image processing technique (KLONK), (Figure 3). It has been determined the existence of two set dyke swarms in the area; (i) The dyke swarm with $\sim$ E-W (mostly WWN-EES, rarely WWSEEN) usual trend has length and thickness, up to $3078 \mathrm{~m}$ and $73.11 \mathrm{~m}$, respectively. (ii) $\sim \mathrm{N}-\mathrm{S}$ (mostly NE-SW, minor NNW-SSE) trending dyke swarm is relatively less traceable and smaller in length and thickness than the first group one. It has maximum length of $834 \mathrm{~m}$ and thickness of $21 \mathrm{~m}$. Cross-cutting field relations on the map suggest that majority of the E-W trending dyke swarms appears to be older than the N-S trending ones. The faults with NE-SW general trend, have length usually $<100 \mathrm{~m}$, however it can be traced as long as $743 \mathrm{~m}$.

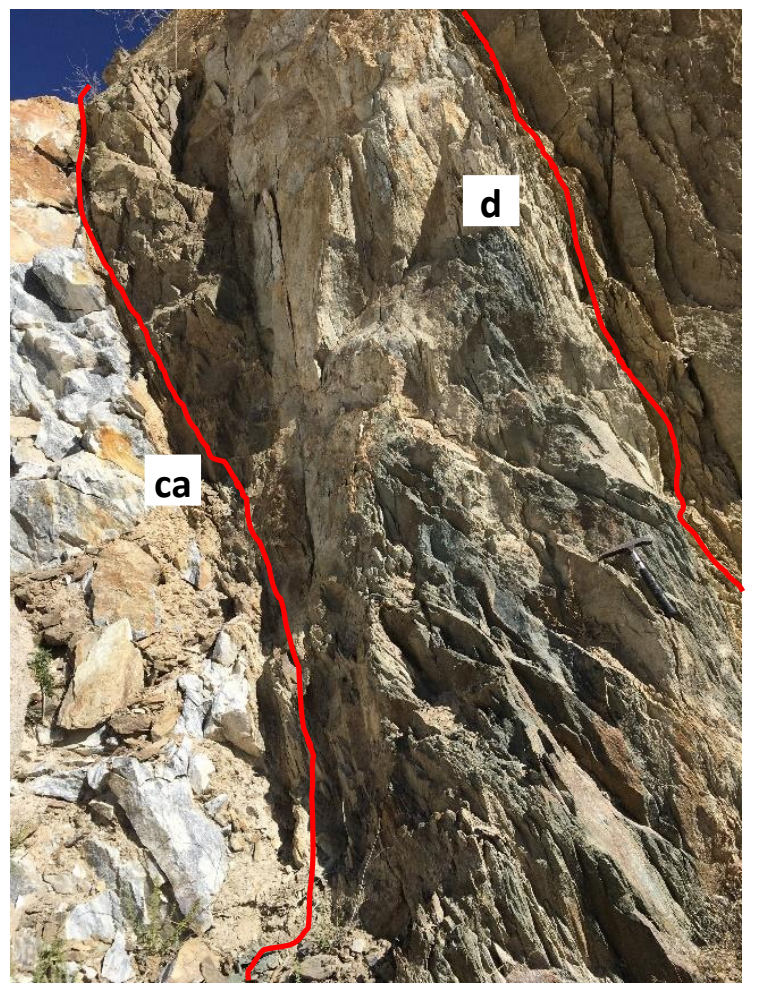

Figure 3. Subvertical mafic dyke (d) intruded into the metacarbonate (ca) of Bozdag formation. Hammer is scale. 


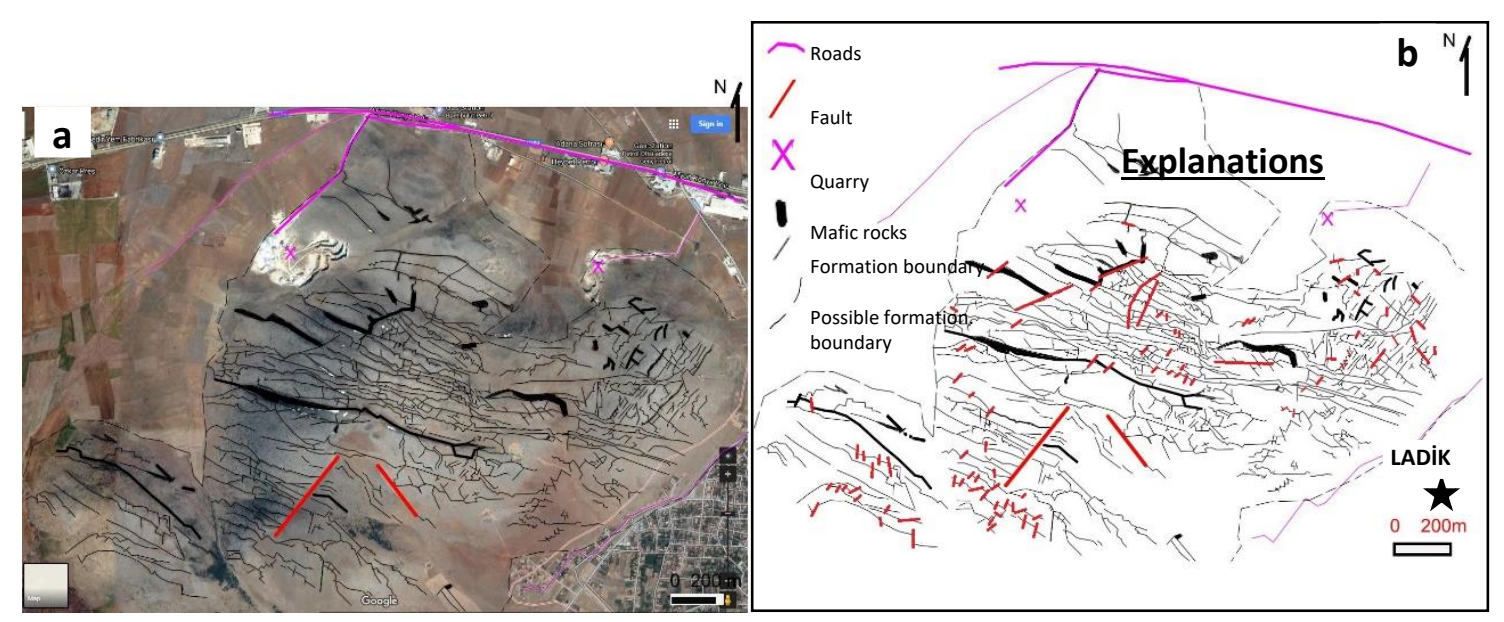

Figure 3: a) A "Google Earth" image of the study area. b) A map showing dyke swarms and faults in the area.

\section{CONCLUSIONS}

Silurian-lower Carboniferous metacarbonates were intruded by two set of mafic dyke swarms, trending in (i) $\sim \mathrm{E}-\mathrm{W}$ and (ii) $\sim \mathrm{N}-\mathrm{S}$ directions. It has been determined by image processing software (KLONK) on Google Earth Images that maximum length and thickness of the dayks are $3078 \mathrm{~m}$ (i), and $73.11 \mathrm{~m}$, respectively. Cross-cutting field relations on the map indicate that majority of the $\sim \mathrm{E}-\mathrm{W}$ trending dyke swarms are older than the $\sim \mathrm{N}-\mathrm{S}$ trending ones.

\section{Acknowledgements}

This work was supported by a grant from Selcuk University and Konya Technical University BAP (Bilimsel Arastırma Projeleri, Koordinatörlüğü, Project No: 17401173), Konya/Turkey.

\section{REFERENCES}

[1] Okay AI. High-pressure/low temperature metamorphic rocks of Turkey., Geol. Soc. Amer. Mem, vol. 164, pp.338-348, 1986.

[2] Goncuoglu MC; Dirik K, Kozlu H. General characteristics of pre-Alpine and Alpine terranes in Turkey: Explanatory notes to the terrane map of Turkey, Annales Geologique de Pays Hellenique, vol. 37, pp.515-536, 1997.

[3] Akal C; Candan O; Koralay EO; Okay A; Oberhänsli R, Chen F. (2008). Early Devonian acidic magmatism in Afyon Zone; preliminary geological, geochemical and geochronological evidence. Paper presented at the 61 th Geological Congress of Turkey, Ankara, Abstracts.

[4] Ernst RE; Head JW; Parfitt E; Grosfils E, Wilson L. Giant Radiating Dyke Swarms on Earth and Venus, Earth-Science Reviews, vol. 39, 1-2, pp.1-58, 1995.

[5] Hou GT; Li JH; Liu YL, Qian XL. The late paleoproterozoic extension event: aulacogens and dyke swarms in the North China craton, Progress in Natural Science, vol. 16, 2, pp.201-208, 2006.

[6] Okay A, Tüysüz O. Tethyan sutures of northern Turkey. In: Durand B, Jolivet L, Horvárt, Séranne M (eds) The mediterranean basins: tertiary extension within the alpine Orogen, Geological Society London Special Publications, vol. 156, pp.475-515, 1999. 
[7] Akal C; Candan O; Koralay OE; Oberhansli R; Chen FK, Prelevic D. Early Triassic potassic volcanism in the Afyon Zone of the Anatolides/Turkey: implications for the rifting of the NeoTethys, International Journal of Earth Sciences, vol. 101, 1, pp.177-194, 2012.

[8] Goncüoğlu MC. GEOLOGY OF THE KÜTAHYA-BOLKARDAĞ BELT MTA Enstitusu Dergisi, vol. 142, pp.223-277, 2011.

[9] Eren Y, Kurt H. The stratigraphical, geochemical and geodynamical modelling of the northeast margin of Menderes-Tauris block, J Fac Eng Arch Selcuk Univ, vol. 15, pp.25-41, 2000.

[10] Robertson AHF, Ustaomer T. Formation of the Late Palaeozoic Konya Complex and comparable units in southern Turkey by subduction-accretion processes: Implications for the tectonic development of Tethys in the Eastern Mediterranean region, Tectonophysics, vol. 473, 1-2, pp.113-148, 2009.

[11] Eren Y. Polyphase Alpine deformation at the northern edge of the Menderes-Taurus block, North Konya, Central Turkey, Journal of Asian Earth Sciences, vol. 19, 6, pp.737-749, 2001. 